\title{
Effects of Pesticides on Nitrous Oxide Production in Sugarcane Cropping Soil ${ }^{+}$
}

\author{
Shilpi Das ${ }^{1,2, *}$, Weijin Wang ${ }^{3}$, Steven Reeves ${ }^{3}$, Ram Dalal ${ }^{1}$ and Peter Kopittke ${ }^{1}$ \\ 1 School of Agriculture and Food Sciences, The University of Queensland, Brisbane QLD 4072, Australia; \\ r.dalal@uq.edu.au (R.D.); p.kopittke@uq.edu.au_(P.K.) \\ 2 Bangladesh Institute of Nuclear Agriculture, BAU campus, Mymensingh 2202, Bangladesh \\ 3 Department of Environment and Science (DES), Dutton Park, Brisbane QLD 4102, Australia; \\ weijin.wang@des.qld.gov.au (W.W.); steven.reeves@des.qld.gov.au (S.R.) \\ * Correspondence: shilpi.das@uq.edu.au; Tel.: +61-470-379-793 \\ + Presented at the third International Tropical Agriculture Conference (TROPAG 2019), Brisbane, Australia, \\ 11-13 November 2019.
}

Published: 6 January 2020

\begin{abstract}
This study aimed to assess the non-target impacts of pesticides on soil biological processes, particularly $\mathrm{N}_{2} \mathrm{O}$ emissions and improve understanding of the contributions of nitrification and denitrification to $\mathrm{N}_{2} \mathrm{O}$ production in sugarcane soils. We conducted a laboratory incubation experiment, in which a herbicide Roundup ${ }^{\circledR}$, an insecticide Confidor ${ }^{\circledR}$, a fungicide Shirtan ${ }^{\circledR}$, and a fumigant metam sodium were added to a Ferrosol and then incubated at $25^{\circ} \mathrm{C}$ for 38 days at 2 moisture regimes ( $55 \%$ and $90 \%$ water holding capacity (WHC)). At day 28 , soil water contents in the $55 \%$ WHC treatments were also increased to $90 \%$ WHC to create a condition to favour denitrification. The $55 \%$ and $90 \%$ WHC treatments received $\mathrm{NH}_{4} \mathrm{SO}_{4}$ at $40 \mu \mathrm{g} \mathrm{N} \mathrm{g}{ }^{-1}$ dry soil and $\mathrm{KNO}_{3}$ at $40 \mu \mathrm{g} \mathrm{N} \mathrm{g}{ }^{-1}$ dry soil, respectively, with $\mathrm{K}^{15} \mathrm{NO}_{3}$ added at $2 \mu \mathrm{g} \mathrm{N} \mathrm{g}{ }^{-1}$ of dry soil in all treatments. Compared with the control treatment, Confidor application significantly increased net nitrification rates and $\mathrm{N}_{2} \mathrm{O}$ emissions at 55\% WHC. After increasing water content from 55\% to $90 \%$ WHC at day 28 , net denitrification occurred in the metam sodium treatment; $\mathrm{N}_{2} \mathrm{O}$ emissions increased in the order: metam sodium > Shirtan > Glyphosate treatment, with little changes in the Confidor and control treatments. During the 38-day incubation at $90 \%$ WHC, the metam sodium treatment emitted more $\mathrm{N}_{2} \mathrm{O}$ emissions than other treatments in the first 15 days of the incubation but no significant differences were observed among the other treatments at the end of the incubation.
\end{abstract}

Keywords: $\mathrm{N}_{2} \mathrm{O}$ production; pesticides; sugarcane cropping soil

Acknowledgments: We are grateful to the Bangabandhu Science and Technology Fellowship Trust (BSTFT), Bangladesh for support of the first author through a PhD scholarship. Authors acknowledge the assistance of Marijke Heenan from DES, QLD for soil sampling and the laboratory analysis.

Conflicts of Interest: The authors declare no conflict of interest.

(C) 2020 by the authors. Licensee MDPI, Basel, Switzerland. This article is an open access article distributed under the terms and conditions of the Creative Commons Attribution (CC BY) license (http://creativecommons.org/licenses/by/4.0/). 